\title{
THE APPLICATION OF HEMODIALYSIS TO THE TREATMENT OF BARBITURATE POISONING ${ }^{1}$
}

\author{
By LAURENCE H. KYLE, HAROLD JEGHERS, WILLIAM P. WALSH, PAUL D. \\ DOOLAN, HENRY WISHINSKY, AND ARTHUR PALLOTTA
}

(From the Department of Medicine, Georgetown University Medical Center, Washington, D. C.)

(Submitted for publication August 20, 1952; accepted January 7, 1953)

Current methods of treatment of barbiturate poisoning, which consist of supportive measures aimed towards maintenance of life until the drug can be excreted or metabolized, have occasioned considerable dissatisfaction because of their lack of specificity. Ideal therapy must be directed toward either more rapid removal or accelerated detoxification of the barbiturate preparation. The closest approach to this goal has been the use of massive intravenous infusions to initiate diuresis with consequently more rapid urinary excretion of the drug.

Morbidity and mortality in a significant number of patients with barbiturate toxicity are not directly related to the primary depressant effect of the drug. Many patients, especially in the older age group, die because of respiratory difficulties. Morbidity at all ages is often increased by such complications. The number and severity of these could be reduced if the drug were removed from the body more rapidly, thus shortening the period of coma.

The application of massive hydration (1) or cross-circulation of a poisoned dog with a large untreated animal (2) has been shown to permit survival of narcotized dogs given doses of barbiturate that ordinarily prove fatal. These studies indicated that permanent fixation of barbiturate to tissues is not the major factor in mortality and strongly suggested that beneficial effect might result from lowering of the blood barbiturate level, irrespective of the total amount of barbiturate contained within the body.

Hemodialysis will not remove substances that are firmly attached to protein. Brodie and his associates (3) have presented evidence that only a certain portion of the circulating barbiturate is so

1 This investigation was supported by a research grant (R.G. 2741) from the National Institutes of Health, U. S. Public Health Service. Part of this material was presented at the National Meeting, American Federation for Clinical Research, May 1952. bound and there is a possibility that the binding is loose, a form of equilibrium existing between the bound and the unbound portions. On this premise it appeared worthwhile to ascertain the possibility of removing barbiturate from the body by means of hemodialysis.

\section{METHODS}

The instrument used for hemodialysis in this investigation was the Kolff type of artificial kidney, modified and utilized extensively by Merrill and his associates (4, 5) and studied further by Wolf, Remp, Kiley, and Currie (6).

Determination of the barbiturate content of the blood, urine and bath fluid was carried out in early experiments by a method (Method A) which combined the salient features of several previously described procedures (7-9). In later experiments, the procedure (Method B) of Goldbaum was employed (10). Both methods employed, as well as other methods of barbiturate analysis, suffer from a lack of specificity since they do not differentiate between the barbiturate, a breakdown product or a metabolic coupling product.

\section{Method $A$}

Blood: Five ml. of oxalated blood, buffered to $\mathrm{pH} 5.5$ with $1 \mathrm{M} \mathrm{KH}_{2} \mathrm{PO}_{4}$, was extracted with $50 \mathrm{ml}$. of chloroform. An aliquot of the filtered chloroform extract, usually $40 \mathrm{ml}$., was then extracted with two portions $(5 \mathrm{ml}$. and $3 \mathrm{ml}$.) of $0.2 \mathrm{NaOH}$. Nitrogen gas was bubbled through this combined alkaline extract to remove any dissolved chloroform, and the volume was brought up to $10 \mathrm{ml}$. An aliquot of $5 \mathrm{ml}$. was removed and added to an equal volume of borate buffer which adjusted the solution to $\mathrm{pH}$ 10. The optical density at $240 \mathrm{~m} \mu$ was determined in the Beckman D.U. spectrophotometer and the amount of barbiturate estimated from the optical densities of standard solutions of the barbiturate in similarly buffered solvent. Whenever possible the concentration of barbiturate in blood was corrected by subtracting the apparent concentration of similarly treated blood obtained from the patient before the administration of any drug. This blank value varied; but the average of 25 determinations revealed it to be about $0.45 \mathrm{mg}$. per $100 \mathrm{ml}$. of blood

Bath and urine: For analysis of bath or urine, samples of $50 \mathrm{ml}$. were extracted with $50 \mathrm{ml}$. of chloroform and the procedure followed as described previously under blood. 
TABLE I

Recovery of barbiturate from bath fiuid by Methods $A$ and $B$

\begin{tabular}{|c|c|c|c|c|c|c|}
\hline \multirow{3}{*}{$\begin{array}{l}\text { Concentration } \\
\text { me. } / 50 \mathrm{ml} \text {. }\end{array}$} & \multirow{3}{*}{$\underset{m g . / T B^{*}}{\text { Equivalent to }}$} & \multirow[b]{3}{*}{ Barbiturate } & \multirow{2}{*}{\multicolumn{2}{|c|}{$\begin{array}{c}\begin{array}{c}\text { Recovered } \\
\text { ms. } / 50 \mathrm{ml} .\end{array} \\
\text { Method }\end{array}$}} & \multirow{2}{*}{\multicolumn{2}{|c|}{$\begin{array}{l}\text { Per cent } \\
\text { recovery }\end{array}$}} \\
\hline & & & & & & \\
\hline & & & A & B & A & B \\
\hline .010 & 20 & $\begin{array}{l}\text { Amytal } \\
\text { Nembutal } \\
\text { Phenobarb. } \\
\text { Barbital }\end{array}$ & $\begin{array}{l}.047 \\
.050 \\
.017 \\
.020\end{array}$ & $\frac{.011}{.012}$ & $\begin{array}{l}470 \\
500 \\
170 \\
200\end{array}$ & $\frac{110}{120}$ \\
\hline .025 & 50 & $\begin{array}{l}\text { Amytal } \\
\text { Nembutal } \\
\text { Phenobarb. } \\
\text { Barbital }\end{array}$ & $\begin{array}{l}.115 \\
.028 \\
.062 \\
.015\end{array}$ & $\frac{.026}{\overline{0}}$ & $\begin{array}{r}460 \\
112 \\
250 \\
60\end{array}$ & $\frac{104}{112}$ \\
\hline .035 & 70 & $\begin{array}{l}\text { Amytal } \\
\text { Nembutal }\end{array}$ & $\begin{array}{l}.170 \\
.018\end{array}$ & - & $\begin{array}{r}486 \\
51\end{array}$ & - \\
\hline .050 & 100 & $\begin{array}{l}\text { Amytal } \\
\text { Nembutal } \\
\text { Barbital }\end{array}$ & $\begin{array}{l}.065 \\
.060 \\
-\end{array}$ & $\frac{.054}{.050}$ & $\begin{array}{l}130 \\
120 \\
-\end{array}$ & $\frac{108}{100}$ \\
\hline .075 & 150 & Amytal & .064 & .075 & 85 & 100 \\
\hline .100 & 200 & Amytal & .076 & .094 & 76 & 94 \\
\hline .125 & 250 & $\begin{array}{l}\text { Amytal } \\
\text { Nembutal } \\
\text { Phenobarb. } \\
\text { Barbital }\end{array}$ & $\begin{array}{l}.112 \\
.138 \\
.125 \\
.058\end{array}$ & $\bar{z}$ & $\begin{array}{r}96 \\
116 \\
100 \\
46\end{array}$ & $\frac{-}{99}$ \\
\hline .250 & 500 & $\begin{array}{l}\text { Amytal } \\
\text { Nembutal } \\
\text { Phenobarb. } \\
\text { Barbital }\end{array}$ & $\begin{array}{l}.218 \\
.305 \\
.195 \\
.110\end{array}$ & $\frac{\bar{Z}}{.250}$ & $\begin{array}{r}87 \\
122 \\
78 \\
44\end{array}$ & $\bar{z}$ \\
\hline
\end{tabular}

* TB = total bath.

TABLE II

Recovery of barbiturate from urine by Method $A$

\begin{tabular}{|c|c|c|c|c|}
\hline $\begin{array}{l}\text { Concentration } \\
\text { me. } 150 \mathrm{ml} .\end{array}$ & $\begin{array}{l}\text { Equivalent to } \\
\text { ms./L. }\end{array}$ & Barbiturate & $\begin{array}{l}\text { Recovered } \\
\text { Method A }\end{array}$ & $\begin{array}{l}\text { Per cent } \\
\text { recovered } \\
\text { Method A }\end{array}$ \\
\hline 1.00 & 20 & $\begin{array}{l}\text { Amytal } \\
\text { Nembutal } \\
\text { Phenobarb. } \\
\text { Barbital }\end{array}$ & $\begin{array}{l}.92 \\
1.20 \\
1.41 \\
0.39\end{array}$ & $\begin{array}{r}92 \\
120 \\
141 \\
39\end{array}$ \\
\hline 2.50 & 50 & $\begin{array}{l}\text { Amytal } \\
\text { Nembutal } \\
\text { Phenobarb. } \\
\text { Barbital }\end{array}$ & $\begin{array}{l}2.17 \\
2.84 \\
1.76 \\
0.72\end{array}$ & $\begin{array}{r}87 \\
118 \\
70 \\
29\end{array}$ \\
\hline 5.0 & 100 & $\begin{array}{l}\text { Amytal } \\
\text { Nembutal } \\
\text { Phenobarb. } \\
\text { Barbital }\end{array}$ & $\begin{array}{l}5.20 \\
5.31 \\
3.66 \\
1.64\end{array}$ & $\begin{array}{r}104 \\
106 \\
73 \\
33\end{array}$ \\
\hline
\end{tabular}

\section{Method $B$}

Blood and urine: The method as described in (10) was followed.

Bath: Since the levels found in the bath were occasionally as low as $20 \mathrm{mg}$. in 100 liters of bath, much larger aliquots were required for extraction in order to obtain concentrations of barbiturate in the $\mathrm{NaOH}$ extracts that would provide accurate optical density readings. In order to extract these larger aliquots efficiently it was found necessary to use the following procedure: $50 \mathrm{ml}$. of bath fluid were adjusted to $\mathrm{pH} 5.5$ with $1 \mathrm{M} \mathrm{KH_{2 }} \mathrm{PO}_{4}$ and extracted three times with 100,50 , and $50 \mathrm{ml}$. portions of chloroform. The pooled chloroform extract was then washed with $10 \mathrm{ml}$. of phosphate buffer ( $\mathrm{pH} 7.4$ ) once 
and filtered. A $175 \mathrm{ml}$. portion of this filtered chloroform extract was then extracted with $10 \mathrm{ml}$. of $0.45 \mathrm{~N}$ $\mathrm{NaOH}$. Thereafter the procedure described for the determination of blood barbiturate was followed.

Recovery of the different barbiturates from urine and bath fluid is listed in Tables I and II. It can be seen that with increased concentration in the bath fluid, precision in the analysis of the barbiturate is also increased. It is also evident that bath samples of less than $100 \mathrm{mg}$. per total bath cannot be analyzed by Method A, unless, instead of $50 \mathrm{ml}$., a $100 \mathrm{ml}$. portion of bath is used; or if the chloroform is extracted with $5 \mathrm{ml}$. rather than $10 \mathrm{ml}$. of $\mathrm{NaOH}$. With this modification levels as low as $50 \mathrm{mg}$. per total bath could be analyzed. In Goldbaum's method (B) levels as low as $\mathbf{2 0} \mathrm{mg}$. of barbiturate per total bath could be determined with a reasonable degree of accuracy.

Recovery from blood of $100 \pm 5$ per cent could be demonstrated by Method A in determining blood barbiturate content in samples of blood containing concentrations ranging from $0.5 \mathrm{mg}$. to $2.0 \mathrm{mg}$. per $100 \mathrm{ml}$. Goldbaum (10) mentions that differences of $0.1 \mathrm{mg}$. per $100 \mathrm{ml}$. of blood could be detected by his method and we have found this to be true.

i

\section{RESULTS}

Initially, patients who were to undergo hemodialysis because of renal disease were given a barbiturate preparation to determine whether the drug could be recovered from the dialysate fluid. Identification of the presence of barbiturate in the bath fluid indicated that this drug was dialyzable but gave no quantitative measure of its removal.

To compare excretion of barbiturate with its removal by hemodialysis, the urinary excretion of phenobarbital and sodium amytal, in terms of per cent of a given dose over a given period of time, was compared with the removal of these drugs by the artificial kidney. Patients without clinical evidence of kidney disease served as subjects for comparison with those dialyzed. The results are shown in Figure 1. In a period of two and one-half hours, 4 per cent of the phenobarbital was excreted in the urine while in the same period of time 66 per cent of the same dose of this drug was removed by hemodialysis. Expressed in different terms, removal by dialysis was 16 times greater than excretion in the urine over the same period of time. In a period of four hours 0.5 per cent of a given dose of sodium amytal was recovered in the urine as compared with removal of 18 per cent by hemodialysis, indicating that removal by dialysis was 36 times more efficient than urinary excretion. The actual per cent of phenobarbital recovered was much greater than that of sodium amytal, most probably attributable to the fact that sodium amytal is metabolized more rapidly.

Urinary excretion of barbiturate, in patients with barbiturate poisoning, was then compared with removal by dialysis in a patient given a dose of the drug sufficient to bring his blood level into a range comparable to that found in the patients with poisoning. It was observed that excretion of barbiturate, even in the patients who had ingested large amounts of this drug, in no way compared with removal by dialysis in a patient with a

BARBITURATE EXCRETION IN URINE AND IN KIONEY BATH
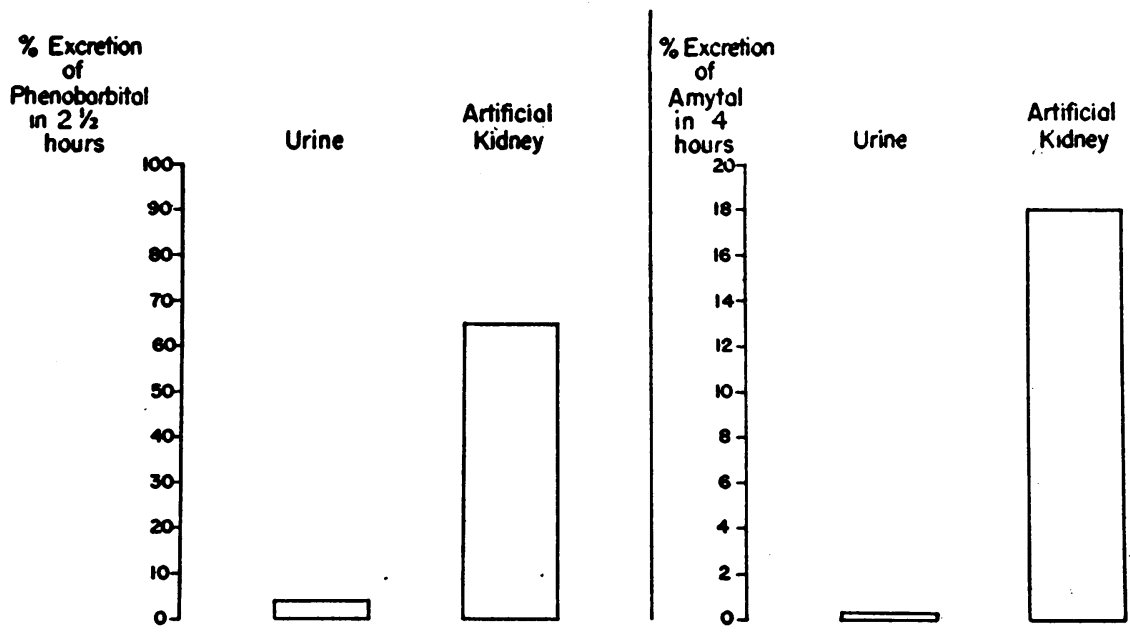

Frg. 1 


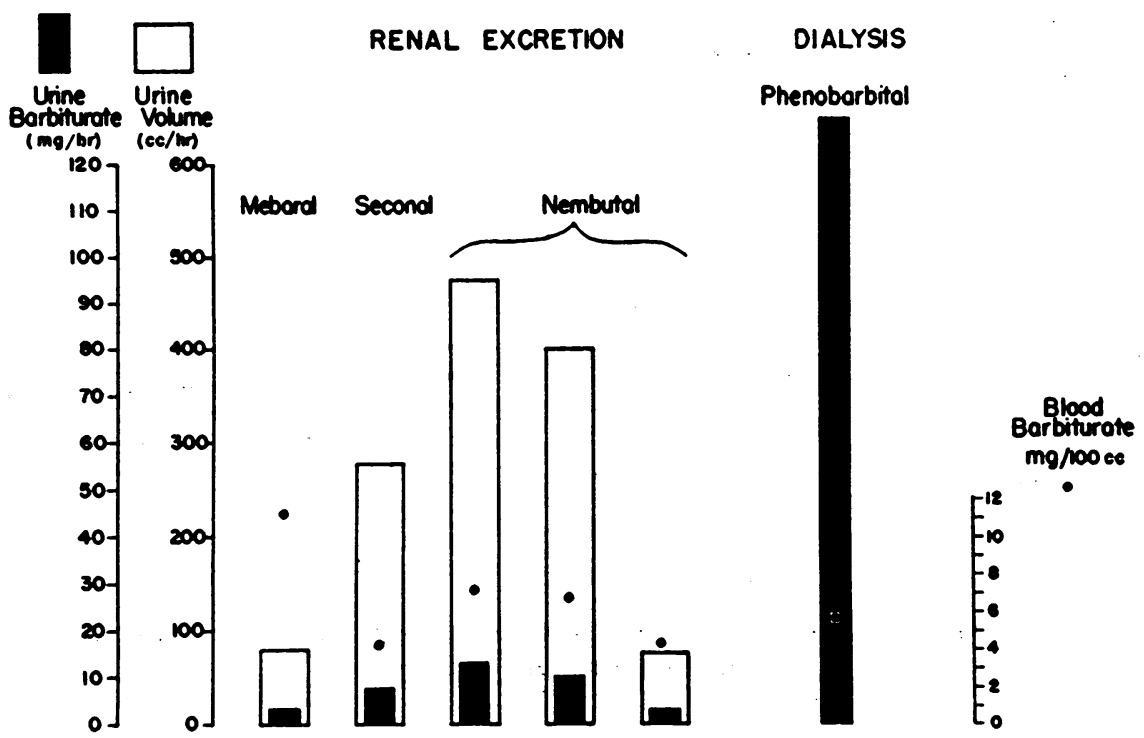

Fig. 2. Comparison of the Urinary Excretion of Barbiturate in Patients with Barbiturate Poisoning with Removal by Hemodialysis in a Control. SubJect

similar blood barbiturate level (Figure 2). It will be noted that, except in a patient with Meberal poisoning, blood barbiturate levels were similar in all cases. The maximum urinary excretion of barbiturate was $12 \mathrm{mg}$. per hour in a patient with a blood level of $7 \mathrm{mg}$. per $100 \mathrm{ml}$. of blood, who, because of intense hydration, had a urine volume of $480 \mathrm{ml}$. per hour. Removal by dialysis in the control patient was $132 \mathrm{mg}$. per hour -11 times greater than the maximum urinary excretion. This comparison is somewhat negated by the fact that the patient who underwent dialysis had received phenobarbital which is not metabolized as rapidly as the preparations ingested by the patients with poisoning. On the other hand, although the blood barbiturate levels were comparable, the actual body stores of barbiturate in the poisoned cases should have been much greater than in the control subject. Thus the removal of barbiturate by the most effective method of therapy currently available compared poorly with that accomplished by the method to be proposed.

In order to evaluate the effect of hemodialysis on barbiturate blood levels, a patient under treatment by hemodialysis because of acute renal insufficiency was given a known dose of sodium amytal. Blood drawn from both the arterial and venous sides of the artificial kidney was measured for barbiturate before and during dialysis, and hematocrit determinations on these specimens were conducted to evaluate the possibility that a changing plasma volume might affect blood barbiturate levels. Two hundred milligrams of sodium amytal were administered intramuscularly two and onehalf hours before, and again one-half hour after the beginning of dialysis. This study revealed that the blood barbiturate level was at all times lower on the venous side of the circuit, indicating that barbiturate was being removed from the blood during its course through the artificial kidney (Figure 3 ). The arterial and venous blood barbiturate levels followed each other closely during dialysis and the arterial and venous hematocrit values showed no significant change during the six hour period, indicating that the changing blood levels were due to actual removal of barbiturate. During the first three hours of dialysis $96 \mathrm{mg}$. of barbiturate were recovered from the bath fluid but subsequent samples contained insufficient barbiturate to allow accurate measurement by the technique employed (Method A). However, it was apparent that at least 25 per cent of the given dose had been removed by dialysis and in view of the continued differential between venous and arterial levels it is probable that a greater amount had been removed. This patient most probably maintained a significant blood concentration of this rapidly metabolized barbiturate preparation because of the 

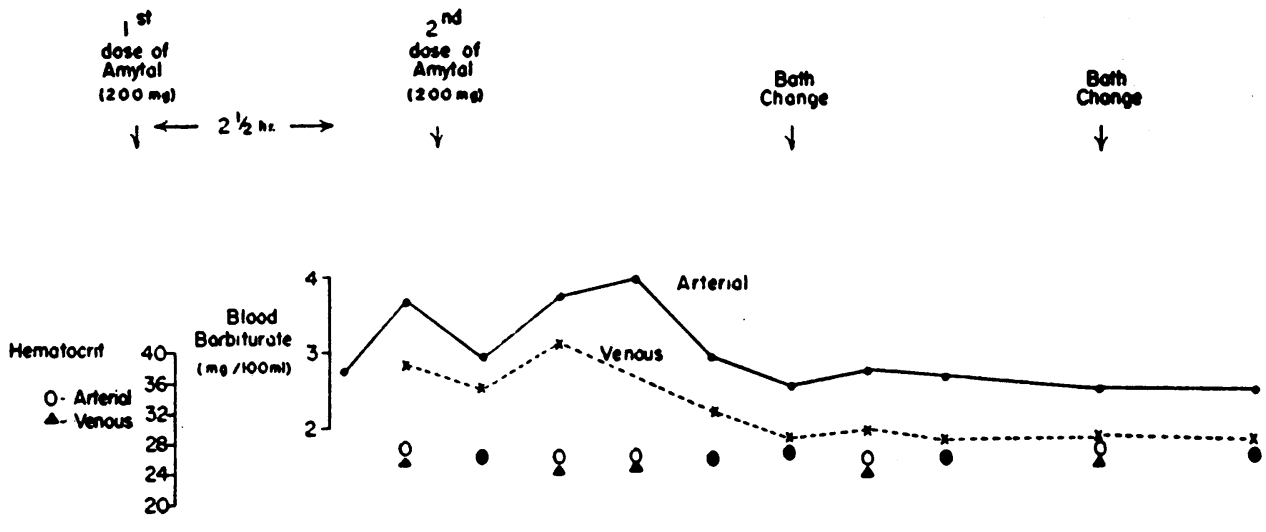

Flow rate

190 107

200

Fig. 3. The Effect of Hemodialysis on Blood Barbiturate levels in a Patient Given a Known Amount of Drug
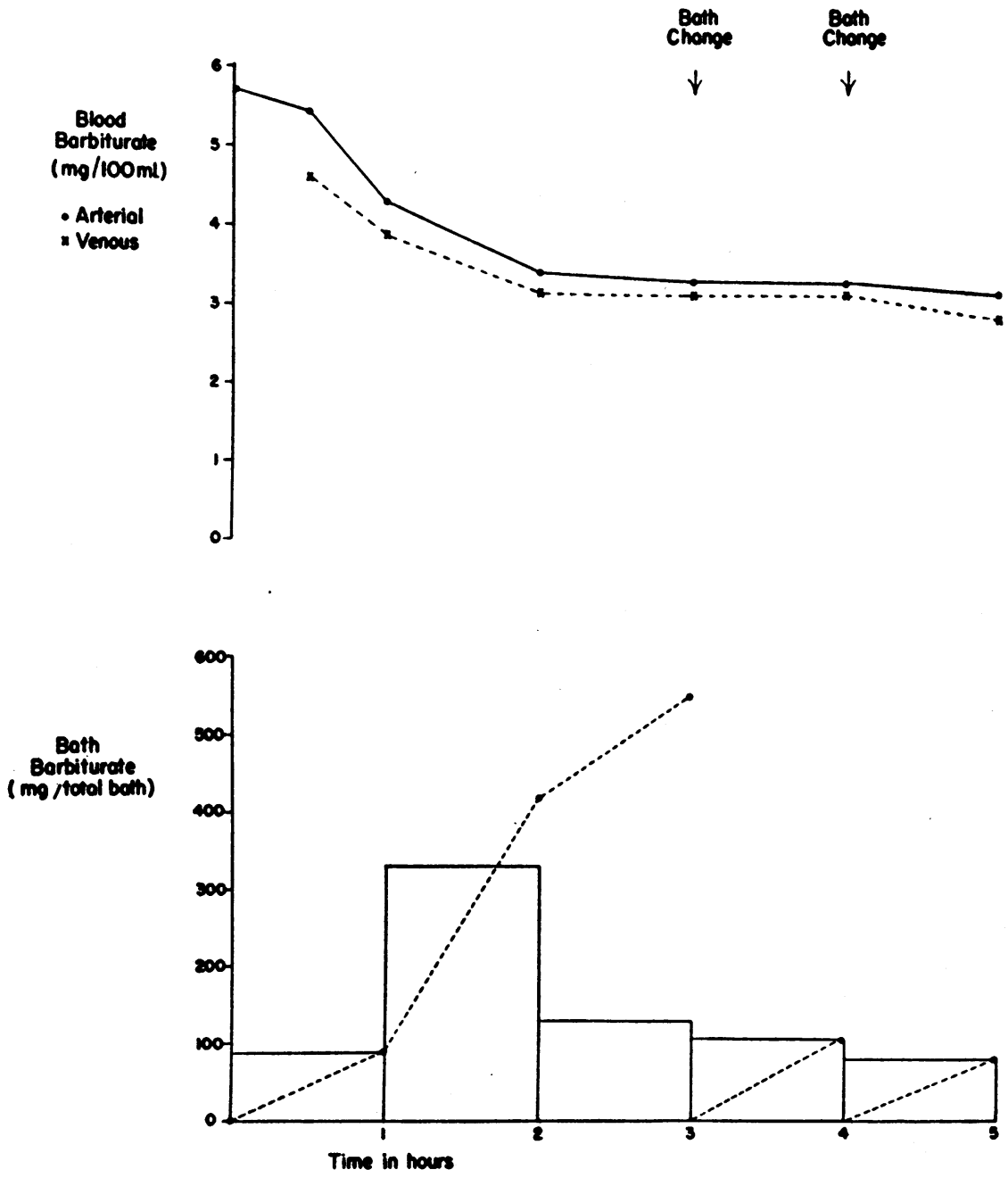

Fig. 4. The Effect of Hemodialysis on Blood and Bath Barbiturate in a Patient with Poisoning (CASe 1) 
presence of severe hepatic damage on the basis of carbon tetrachloride poisoning.

Following these preliminary studies it became possible to treat two patients with severe barbiturate poisoning by means of hemodialysis.

Case 1. The first patient was a woman of 50 years who had ingested an unknown amount of Nembutal at an unknown time prior to her admission to another hospital. At this time she was comatose, unresponsive to all stimuli and completely areflexic. The patient was given routine therapy in the form of an airway, removal of bronchial secretions, antibiotics, analeptics and constant infusions. In spite of this treatment she remained in deep coma, and, after 36 hours, began to fail rapidly. The blood pressure began to fall, atelectasis developed and tracheotomy became necessary. At this time dialysis was conducted. At the beginning of the procedure the blood pressure was $80 / 40 \mathrm{~mm} . \mathrm{Hg}$, she was areflexic, and, in spite of constant suction through the tracheotomy tube, was mildly cyanotic. During a five hour period of dialysis by the artificial kidney her condition steadily improved. At the end of one and one-half hours the blood pressure began to rise, and at the end of four hours her deep tendon reflexes could be elicited for the first time since hospitalization. At the termination of dialysis the blood pressure was normal, deep tendon reflexes were present and she responded by movement to $3 \mathrm{mg}$. of intravenous picrotoxin, whereas prior to this procedure she had shown no response to continued large intravenous doses of this drug. The patient regained complete consciousness eight hours following dialysis and made an uneventful recovery. The blood barbiturate level was $5.9 \mathrm{mg}$. at the onset, and $3.0 \mathrm{mg}$. at the termination of dialysis. The blood barbiturate level remained approximately constant during the last three hours of dialysis, despite continued removal of barbiturate (Figure 4), suggesting that barbiturate was being removed from extravascular sources. A five hour urine specimen was collected just prior to utilization of the artificial kidney, allowing comparison of removal of barbiturate by urinary excretion and by dialysis. Seven hundred and forty milligrams were removed by dialysis as compared to the urinary excretion of $30 \mathrm{mg}$.- a ratio of $24: 1$ (Figure 5).

Case 2. The second patient was a 34 year old woman who had taken $10 \mathrm{gms}$. of sodium amytal approximately 48 hours preceding dialysis. She was admitted to the emergency room of another hospital 90 minutes after ingestion of the drug and gastric lavage revealed a few small blue particles in otherwise clear fluid. The initial examination revealed a comatose patient unresponsive to all stimuli, with absent corneal reflexes and a fixed gaze. All deep tendon reflexes were absent except for the patellar reflexes which were hyperactive. She responded with purposeless movements to the intravenous administration of $6 \mathrm{mg}$. of picrotoxin.

The patient was treated with the usual methods including massive intravenous fluid therapy but without further analeptics because of her response to the test dose. Her

\section{EXCRETION WN FIVE HOURS}

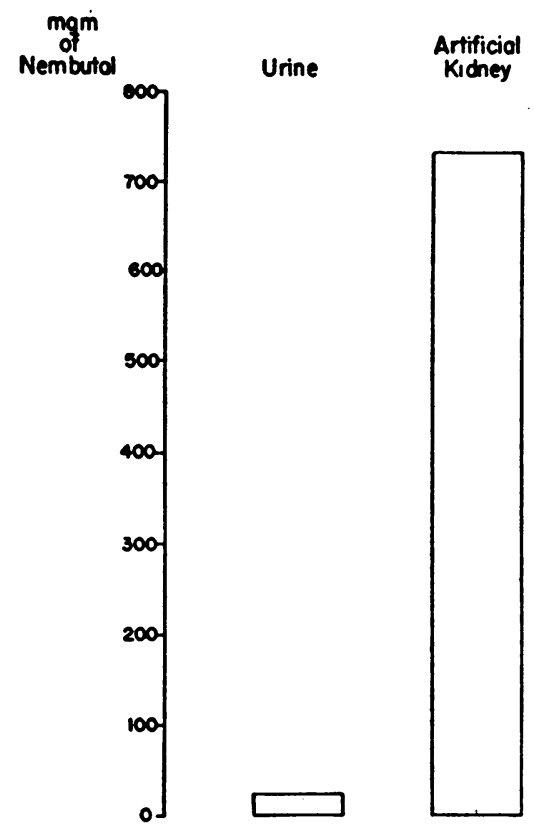

Fig. 5. Comparison of Removal of Barbiturate by Renal Excretion and Dialysis in Case 1

course over the next 38 hours was one of continued coma. The knee jerks alternated between hyperactivity and absence, but the other deep tendon reflexes remained absent. After about 30 hours she developed bilateral ankle clonus and an extensor plantar response; the blood barbiturate level at this time was $5.3 \mathrm{mg}$. per cent. A neurologic consultant believed, in view of the coma, fixed pupils, absent corneal reflexes and changing neurologic signs in the lower extremities, that there was cerebral damage and recommended hemodialysis.

The patient was treated by means of the artificial kidney for four and one-half hours. During the early part of the procedure she developed respiratory distress which necessitated bronchoscopic removal of secretions. Later during dialysis all of the deep tendon reflexes returned, as did the corneal response. The eyes began to roll and ankle clonus became less marked. At the end of three and one-half hours she began to respond to painful stimuli and at the termination of dialysis moved spontaneously. The blood barbiturate level fell during this period of time from 5.2 to $3.5 \mathrm{mg}$. per $100 \mathrm{ml}$. of blood and $300 \mathrm{mg}$. of barbiturate were recovered from the bath (Figure 6). The patient subsequently improved rapidly with increasing spontaneous activity and complete disappearance of the abnormal neurologic signs. She was completely conscious 16 hours following dialysis and subsequently made a complete recovery.

A four hour urine specimen was obtained from the patient immediately prior to dialysis, allowing comparison of the amount of barbiturate in this specimen with the amount obtained during dialysis. Removal in the bath totaled 


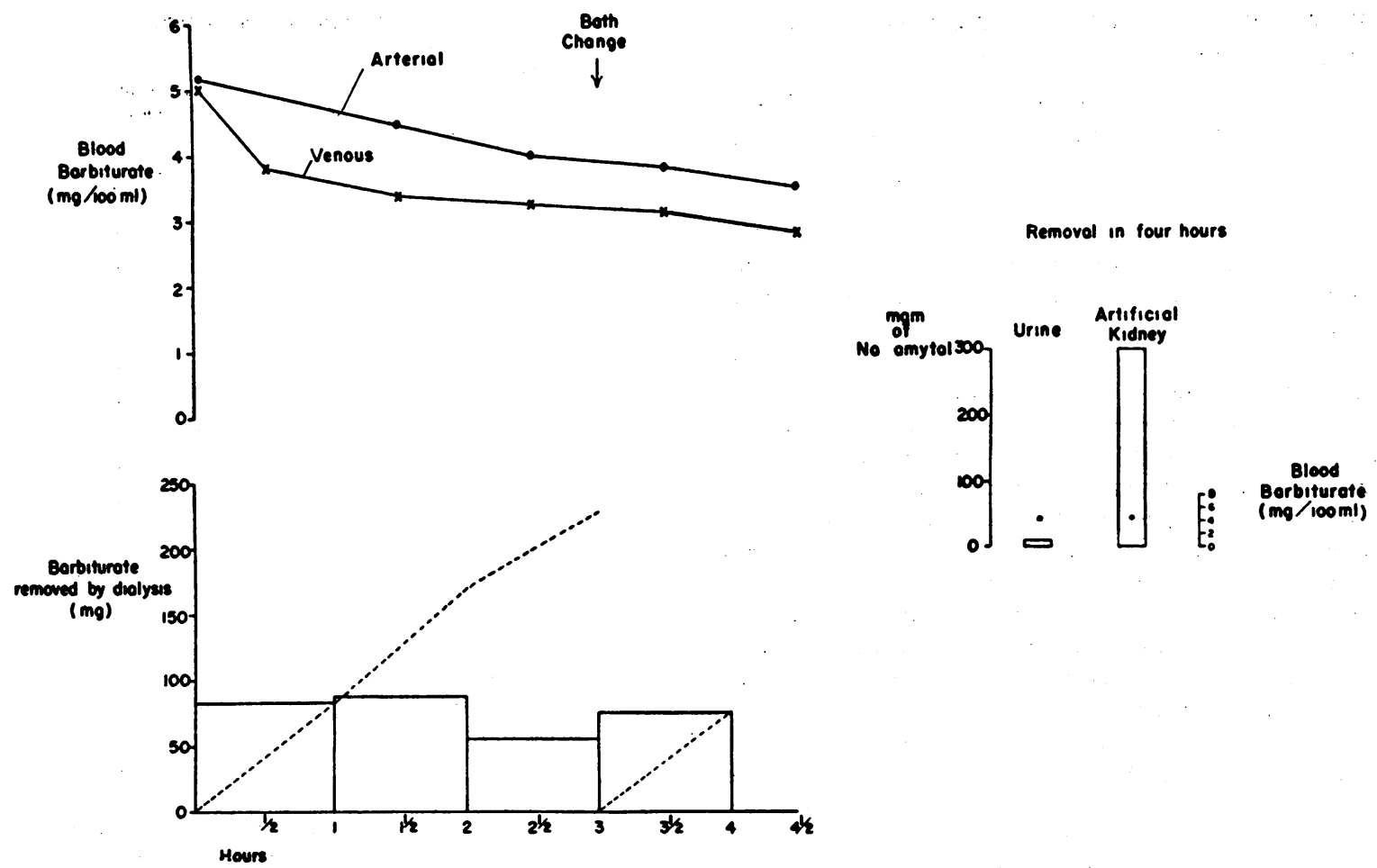

Fig. 6. The Effect of Hemodialysis in Barbiturate Poisoning: Removal by Dialysis Compared with Renal. EXCRETION IN CASE 2

$300 \mathrm{mg}$. over a four hour period as compared to excretion of $10 \mathrm{mg}$. in the urine during the same period of time immediately prior to dialysis when the blood level was slightly higher, 30 times more barbiturate thus being removed by hemodialysis than by urinary excretion (Figure 6).

\section{DISCUSSION}

The problem of barbiturate poisoning is of considerable clinical importance (11) and although constant efforts have been made to effect better methods of treatment, those available at the present time are by no means totally desirable. The removal of barbiturate by hemodialysis is a new approach to this problem which, because of the increasing number of artificial kidneys available, is of practical importance. The artificial kidney has been chiefly used for the removal of endogenous toxins or metabolites. A previous report from this clinic demonstrated that hemodialysis is an effective method whereby acetylsalicylic acid can be removed from the body (12). Merrill has reported the use of the artificial kidney in the therapy of bromide poisoning (13) and has commented on its application to barbiturate intoxication (14).
This preliminary study demonstrates that barbiturate can be removed much more effectively by hemodialysis than by urinary excretion. It has been shown that patients with barbiturate poisoning tolerate the procedure of hemodialysis well and demonstrate improvement in their clinical picture during dialysis. Suggestive data have been obtained that application of vividialysis shortens the period of coma and it appears very possible that this method of treatment may be, in cases of severe poisoning, a life-saving procedure. It remains to be determined whether utilization of the artificial kidney early in the course of poisoning may not shorten materially the period of unconsciousness and thus protect the patient from the severe complications which result from prolonged coma. During this study emphasis was placed on evaluation of the efficacy of the artificial kidney in effecting removal of barbiturate from the body and all evidence supports the value of the procedure. Because of initial fears regarding the safety of hemodialysis, effort was made to treat only those patients who appeared to have little chance of survival without utilization of the artificial kidney. 
The results obtained make it appear that certain advantages might be obtained by hemodialysis in some patients with lesser degrees of barbiturate poisoning soon after the ingestion of the drug.

\section{CONCLUSIONS}

Barbiturate drugs can be removed from the human body effectively by hemodialysis with the Kolff type of artificial kidney.

Comparison of the removal of barbiturate by urinary excretion and by utilization of the artificial kidney indicates that the latter procedure is 20 to 30 times more effective. Data obtained from 2 patients with barbiturate poisoning indicate that 25 to 30 hours are required for urinary excretion of that amount of barbiturate which can be removed by hemodialysis in one hour.

The treatment of severe barbiturate poisoning by hemodialysis appears to be practical and effective.

\section{ACKNOWLEDGMENTS}

We are grateful to Dr. Theodore Koppanyi, Professor of Pharmacology, Georgetown University School of Medicine, for his advice on this problem and to Dr. L. R. Goldbaum of the Army Medical Service Graduate School, for providing us with his unpublished method of barbiturate analysis.

\section{REFERENCES}

1. Cutting, R. A., and Koppanyi, T., The effect of massive intravenous infusions on the course of barbiturate narcosis. Arch. internat. de pharmacodyn. et de thérap., 1938, 60, 395.

2. Koppanyi, T., and Linegar, C. R., Cross-circulation as a method in the study of drug fixation and poisoning. Science, 1942, 96, 562.
3. Brodie, B. B., Mark, L. C., Papper, E. M., Lef, P. A., Bernstein, E., and Rovenstine, E. A., The fate of thiopental in man and a method for its estimation in biological material. J. Pharmacol. \& Exper. Therap., 1950, 98, 85.

4. Merrill, J. P., Thorn, G. W., Walter, C. W., Callahan, E. J., III, and Smith, L. H., Jr., The use of an artificial kidney. I. Technique. J. Clin. Invest., 1950, 29, 412.

5. Merrill, J. P., Smith, S., III, Callahan, E. J., III, and Thorn, G. W., The use of an artificial kidney. II. Clinical experience. J. Clin. Invest., 1950, 29, 425.

6. Wolf, A. V., Remp, D. G., Kiley, J. E., and Currie, G. D., Artificial kidney function: kinetics of hemodialysis. J. Clin. Invest., 1951, 30, 1062.

7. Walker, J. T., Fisher, R. S., and McHugh, J. J., Quantitative estimation of barbiturates in blood by ultra-violet spectrophotometry. I. Analytical method. Am. J. Clin. Path., 1948, 18, 451.

8. Lous, P., Quantitative determination of barbiturates. A modified spectrophotometric method for clinical use. Acta pharmacol. et toxicol., 1950, 6, 227.

9. Goldbaum, L. R., An ultraviolet spectrophotometric procedure for determination of barbiturates. $\mathrm{J}$. Pharmacol. \& Exper. Therap., 1948, 94, 68.

10. Goldbaum, L. R., Determination of barbiturates. Ultraviolet spectrophotometric method with differentiation of several barbiturates. Analyt. Chem., 1952, 24, 1604.

11. Goldstein, S. W., Barbiturates: A blessing and a menace. J. Am. Pharm. A., 1947, 36, 5.

12. Doolan, P. D., Walsh, W. P., Kyle, L. H., and Wishinsky, H., Acetylsalicylic acid intoxication. A proposed method of treatment. J. A. M. A., 1951, 146, 105.

13. Merrill, J. P., and Weller, J. M., Treatment of bromism with the artificial kidney. Ann. Int. Med., 1952, 37, 186.

14. Merrill, J. P., The artificial kidney. New England J. Med., 1952, 246, 17. 